\title{
A New Design of the Universal Test Rig to Measure the Wear Characterizations of Polymer Acetal Gears (Spur, Helical, Bevel, and Worm)
}

\author{
Samy Yousef, ${ }^{1}$ T. A. Osman, ${ }^{2}$ M. Khattab, ${ }^{2}$ Ahmed A. Bahr, ${ }^{2}$ and Ahmed M. Youssef ${ }^{2}$ \\ ${ }^{1}$ Department of Production Engineering and Printing Technology, Akhbar Elyom Academy, 6th of October 12967, Egypt \\ ${ }^{2}$ Department of Mechanical Design and Production Engineering, Cairo University, Giza 12566, Egypt \\ Correspondence should be addressed to Samy Yousef; ahcann@hotmail.com
}

Received 31 May 2015; Accepted 3 August 2015

Academic Editor: Dae-Eun Kim

Copyright (C) 2015 Samy Yousef et al. This is an open access article distributed under the Creative Commons Attribution License, which permits unrestricted use, distribution, and reproduction in any medium, provided the original work is properly cited.

\begin{abstract}
This work aims to study the wear characterization of common types of acetal polymer gears (spur, helical, bevel, and worm) using a new TS universal test rig, in order to obtain reliable results and as a reference when compared with acetal nanocomposite gears later. The TS universal test rig consists of three different units that are connected by a main driver shaft and a pair of constantly meshing metal spur gears, which transfer power to the bevel and worm test units. The first unit is used to test the bevel gears, the second unit is used to test the spur and helical gears, and the third unit is used to test the worm gears. The loading mechanism is similarly designed to block the brake mechanism. Hobbing and milling machines were used to machine an injection-moulded polymer flanges and produce the tested gears. All gear pairs, except the worm gear, have identical gear ratios. The experiments were performed at speed $1420 \mathrm{rpm}$ and the torque was $4 \mathrm{Nm}$. The results showed that the wear rates (in the form of weight loss) of spur gears were consistent with the previous results and the other gear types had larger wear rates.
\end{abstract}

\section{Introduction}

To satisfy the demand for lighter, faster, quieter, more durable, and cost-effective products, innovative designs increasingly include the use of high-performance plastics. In applications ranging from automotive components to office automation equipment, engineering polymers successfully replace metal even in fine critical gears and contribute to superior performance. Many previous gear test rigs were designed and built to measure wear, friction, and thermal characterizations as well as additional noise emission from them. Mao was considered one of the leading researchers in this field. Mao [1] innovated a test rig to continuously measure the wear rate of the gear surface $(\mathrm{mm} / \mathrm{cycle})$ and friction for different gear materials (unreinforced and reinforced) under constant load conditions; the result showed that the wear resistance of the composite polymer gears was increased. Mao [2] used a test rig to concentrate on the gear thermal wear behaviour. Mao et al. [3] measured the friction and wear behaviour of polymer gear (acetal and nylon) and dissimilar material engagements, that is, acetal against nylon and nylon against acetal gears.

Hoskins et al. [4] used the same test rig to study the fundamental characteristics of the generated noise emission by separating its various components; the results demonstrated the effect of increasing surface roughness, wear, and temperature on the respective sound power levels. Dearn et al. [5] also used the same test rig to describe an attempt to control the tribological properties of dry-running polymer gears by directly applying dry film lubricants to the gear tooth flanks.

Hargreaves and Planitz [6] developed a test rig to describe an experiment to assess the energy saving potential of several industrial gear oils. It was found that the required power to run the best and worst performing oils varied by $14.6 \%$, which represents a significant reduction in energy requirements and the potential to minimize the running costs of industrial machinery. The oils with superior performance generally run at lower temperatures and had a higher cost. Düzcükoğlu 


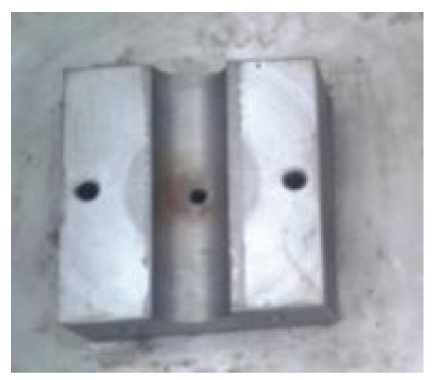

(a)

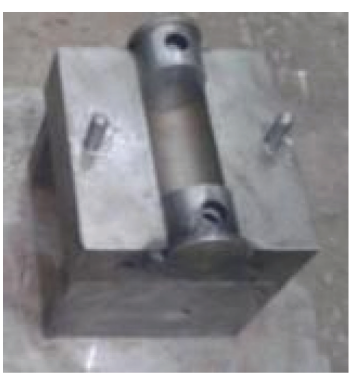

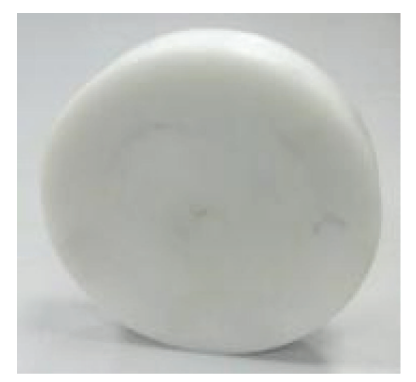

(b)



(c)

FIGURE 1: Injection die and products. (a) Photograph view of short-rod injection die. (b) Product acetal flange. (c) Product acetal short rods.

[7] delayed the thermal-damage formation in the singletooth-meshing region by increasing the tooth width, which decreased the Hertzian surface pressure. Wear tests of the gear pairs and the experimental gear tooth were performed on an FZG. Letzelter et al. [8] developed a new test bench to study the thermal behaviour of polymer gears. The local thermal behaviour of polyamide spur gears was measured using a high-performance infrared camera to provide the temperature distribution. Kirupasankar et al. [9] developed a test rig to study the performance of polymeric gears, and experimental studies were performed to understand the effect of torque on the performance.

Finally, Yousef et al. built a simple test rig to study the wear behaviour of spur gears that made acetal polymer blended by carbon nanotubes [10], which is considered the most type of nanofiller material used in this time to increase the wear resistance of the polymeric material [11, 12]. All previous studies focused on the tribological and thermal behaviour of spur polymeric gears, which motivates the production of polymer (spur, helical, bevel, and worm) gears. The present study investigates the wear behaviour of similar acetal gears engagements (spur, helical, bevel, and worm) using a TS universal test rig, which was particularly designed for this purpose.

\section{Experimental}

2.1. Synthesis of Acetal Polymer Flanges and Short Bars. Polymer flanges were synthesized using an injection-moulding die designed by Yousef et al. $[10,11]$ to produce thick disks with a diameter of $134 \mathrm{~mm}$ and a thickness of $29 \mathrm{~mm}$ after shrinkage. A short bar with similar polymer flanges was made using an injection process; an injection-moulding die was designed and manufactured to synthesize polymer short bars with a diameter of $45 \mathrm{~mm}$ and a length of $80 \mathrm{~mm}$, as shown in Figure 1.

\section{Gears Manufacture}

A hobbing machine was used to produce the tooth of all types of acetal gears (spur, helical, bevel, and worm), as shown in Figure 2. The specifications of the gears are illustrated in Tables 1-4.
TABLE 1: Spur gear specifications.

\begin{tabular}{lc}
\hline Parameters & Value \\
\hline Module & $3 \mathrm{~mm}$ \\
Number of teeth & 27 \\
Pressure angle & $20^{\circ}$ \\
Face width & $20 \mathrm{~mm}$ \\
Centre distance & $81 \mathrm{~mm}$ \\
\hline
\end{tabular}

TABLE 2: Helical gear specifications.

\begin{tabular}{lc}
\hline Parameters & Value \\
\hline Module & $3 \mathrm{~mm}$ \\
Number of teeth & 26 \\
Pressure angle & $20^{\circ}$ \\
Helix angle & $15^{\circ}$ \\
Helix type & Right hand \\
Face width & $20 \mathrm{~mm}$ \\
Centre distance & $81 \mathrm{~mm}$ \\
\hline
\end{tabular}

TABLE 3: Bevel gear specifications.

\begin{tabular}{lc}
\hline Parameters & Value \\
\hline Module & $3 \mathrm{~mm}$ \\
Number of teeth & 30 \\
Outer reference diameter & $94 \mathrm{~mm}$ \\
Pitch cone angle & $45^{\circ}$ \\
Dedendum angle & $3^{\circ}$ \\
Tooth thickness on pitch & $4 \mathrm{~mm}$ \\
Cone distance & $63 \mathrm{~mm}$ \\
\hline
\end{tabular}

\section{TS Universal Test Rig Design}

Figures 3 and 4 show the complete design and photograph of the TS universal test rig, which consists of the following items as illustrated in Table 5. The test rig was built to study the wear characterization of the common types of polymer gears. The advantages of the test rig compared to the traditional gear test rig are that they are inexpensive, easy to use, and small in size.

The test rig consists of three different units: the first unit is used to test bevel gears, the second unit is used to test spur or helical gears, and the third unit is used to test worm gears, as 


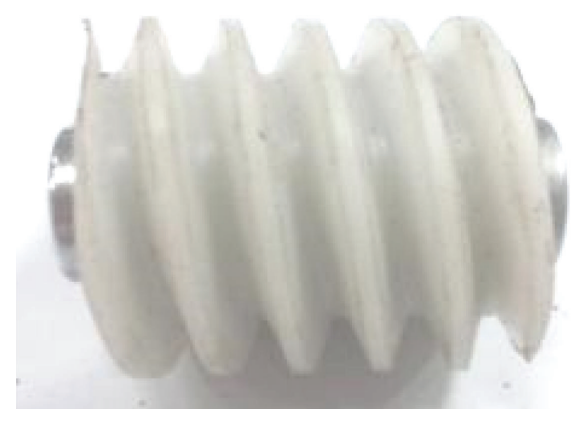

(a)

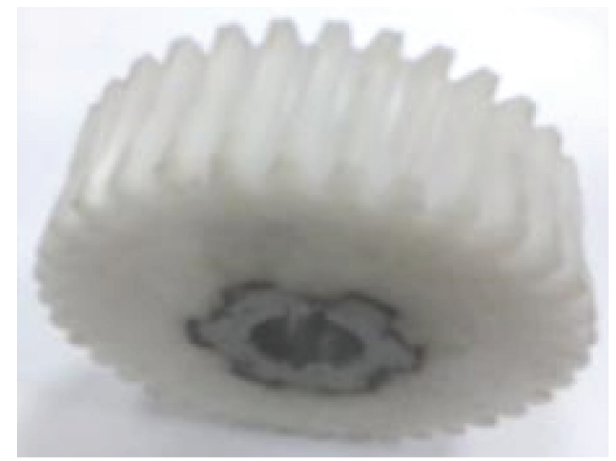

(c)

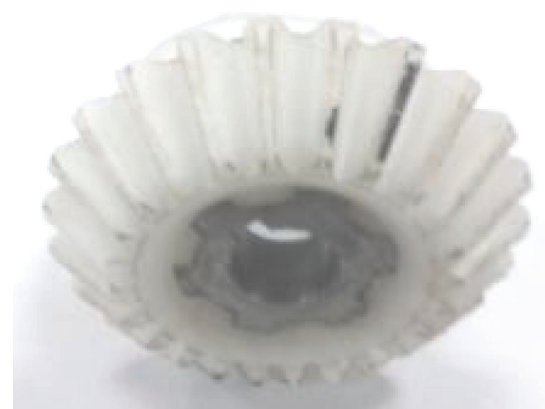

(b)

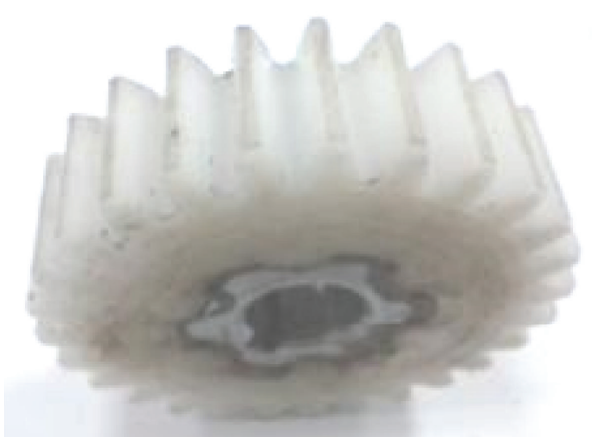

(d)

FIGURE 2: Tested polymer gears: (a) worm gear, (b) bevel gear, (c) wheel gear, and (d) spur gear.

TABLE 4: Worm and wheel gear specifications.

\begin{tabular}{lc}
\hline Parameters & Value \\
\hline Module & $3.15 \mathrm{~mm}$ \\
Number of teeth (worm/wheel) & $2 / 28$ \\
Normal pressure angle & $20^{\circ}$ \\
Pitch diameter (worm/wheel) & $32 / 90 \mathrm{~mm}$ \\
Face width (worm/wheel) & $40 / 29 \mathrm{~mm}$ \\
Axial pitch & $10 \mathrm{~mm}$ \\
Centre distance & $61 \mathrm{~mm}$ \\
\hline
\end{tabular}

shown in Figure 5. These units are connected by a main driver shaft, which is installed on a pair of metal spur gears. The pair of metal spur gears is attached to the speed-controllable DC motor, which has a power of $2 \mathrm{Hp}$ and a rotational speed of $1420 \mathrm{rpm}$. Power was transmitted to the driver polymer gears (spur, helical, bevel, and worm) using a driven metal gear at different torque levels, which started at $4 \mathrm{Nm}$, for two million cycles. For the external torque, only one movable armload was applied on the test unit to be examined, and it was generally applied on the driven unit shaft. The armload was supported between two plates at the end of the arm using the pivot and weight attached with the arm at the other direction. On the other hand, polymeric gears are exposed to lower loads compared with metallic gears. So, only two bearing types were used in the new design: (a) ten deep groove ball bearings had designation 61805 and (b) only one thrust roller bearing had serial code 81105 inserted in worm gear plate to
TABLE 5: Elements of the universal test rig.

\begin{tabular}{lc}
\hline Part number & Description \\
\hline 1 & Motor \\
2 & Flexible coupling \\
3 & Base \\
4 & Polymer bevel gear-set \\
5 & Metallic spur gear-set \\
6 & Polymer spur/helical gear-set \\
7 & Polymer worm gear-set \\
8 & Input shaft \\
9 & Driver shaft \\
10 & Bevel driven gear shaft \\
11 & Spur/helical driven gear shaft \\
12 & Wheel driven gear shaft \\
13 & Worm gear shaft \\
14 & Brakes lever \\
15 & Bevel plates \\
16 & Left support plate \\
17 & Middle support plate \\
18 & Right support plate \\
19 & Wheel gear plates \\
20 & Worm gear plate \\
\hline
\end{tabular}

overcome the axial load which was generated by worm gear. Despite the fact that helical and bevel gears generate also axial 


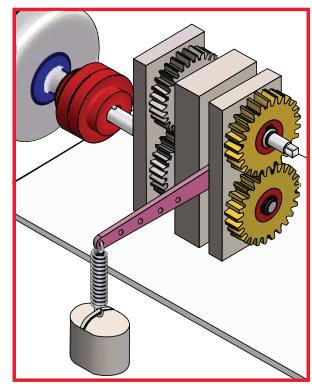

(a) Spur or helical gear testing unit design

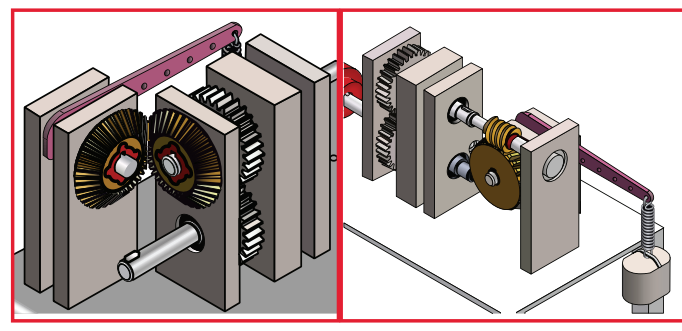

(b) Bevel gear testing unit design

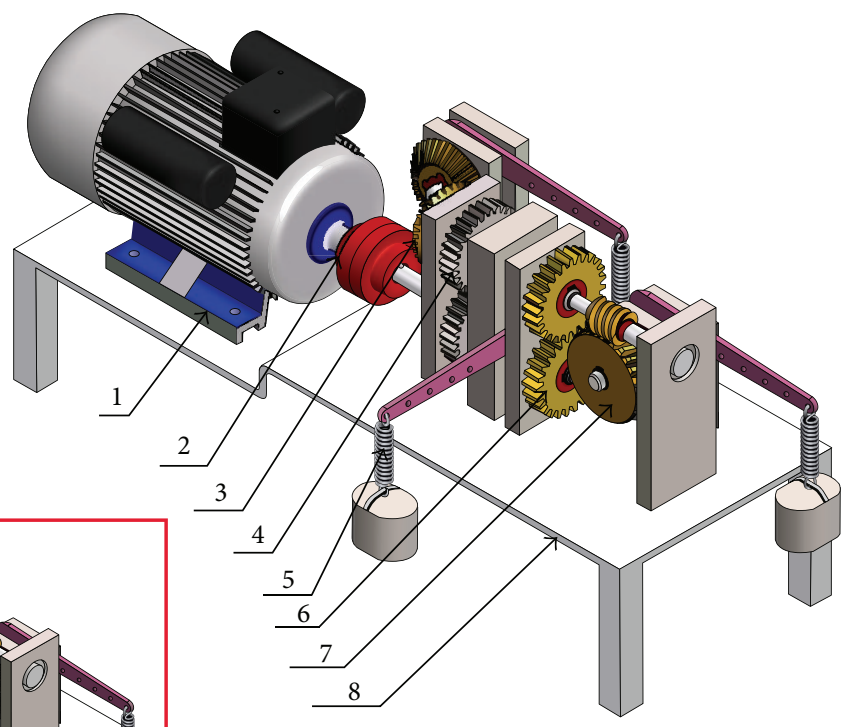

(1) Motor

(2) Coupling

(3) Bevel gear testing unit

(4) Metal gears
(5) Loading mechanism

(6) Spur and helical gear testing unit

(7) Worm gear testing unit

(8) Base



FIGURE 3: Universal test rig design.

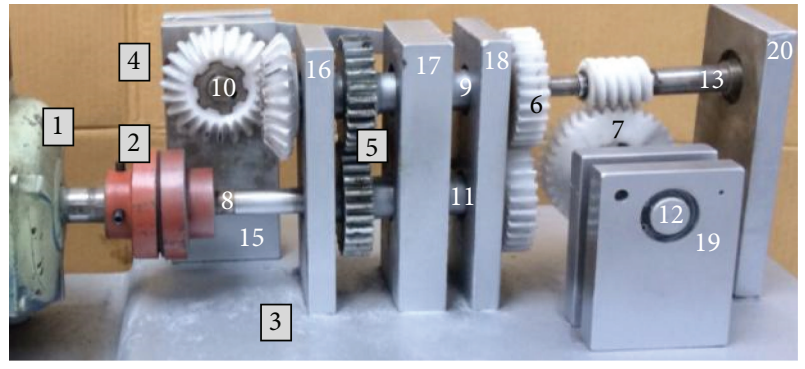

FIGURE 4: A photograph of the universal test rig.

load but much less than caused by worm gear, deep groove ball bearings are considered more economic.

4.1. Loading Mechanism. The test gears are loaded by imposing a torque, which is induced using a dead weight hanging on a load arm that protrudes from the pivot block. According to [1] and referring to Figure 6(a), the relationship between the loaded pivot block and the torque applied to the test gears is simply $W \times L=T_{1}+T_{2}$, where $T_{1}$ and $T_{2}$ are the applied torques on the driver and the driven gears, respectively. If the pair of gears has a gear ratio of $1: 1$, the applied torque is $T=W L / 2$. In the universal test rig, the loading mechanism was designed according to the block brake mechanism as shown in Figures 6(b) and 6(c); the applied friction torque can be calculated using (1), where $A$ is the block contact area, $\mu$ is the coefficient of friction for lining, and $F$ is the weight. The positive sign is used for the direction in Figure 6(b) and the negative sign for the opposite rotation (greater torque):

$$
T=\frac{F a r \mu}{(C \pm \mu b) A} .
$$




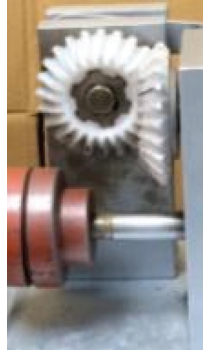

(a)

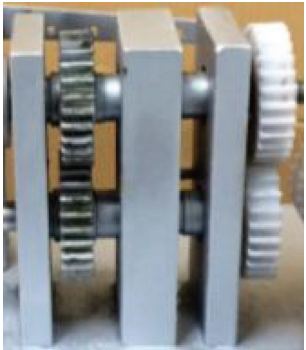

(b)

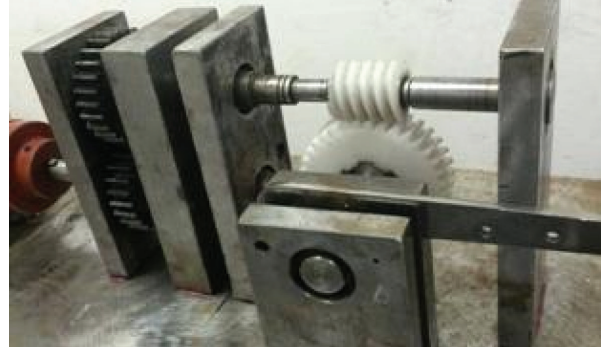

(c)

FIGURE 5: Photograph views for (a) bevel gear testing unit, (b) spur/helical gear testing unit, and (c) worm gear testing unit.

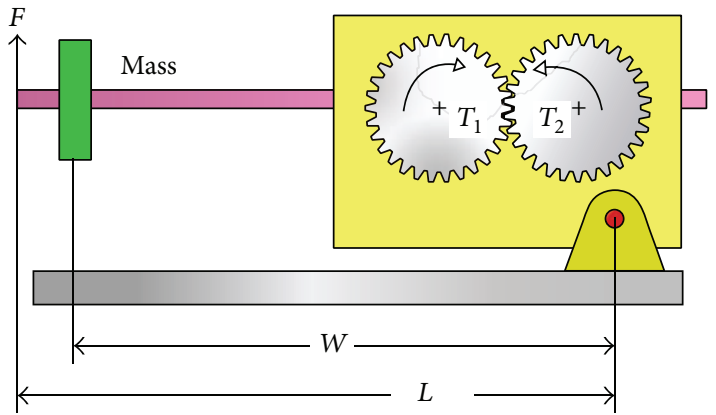

(a)

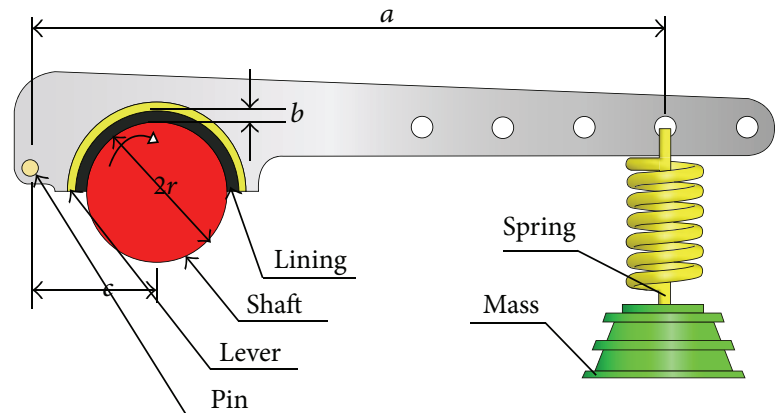

(b)



(c)

FIGURE 6: (a) Load principle of the Mk I test rig 1993, (b) TS universal test rig loading mechanism, and (c) a photograph view of load mechanism.

For the block contact area $(A)$, under the applied load, the contact in our system occurred completely between half lining ring with width $\left(l_{w}=15 \mathrm{~mm}\right)$ and half surface area of driver shaft ( $r$ ), and $A$ was calculated through (2), where $\pi r$ is the circumference of the semicircle of the driver shaft

$$
A=\pi r * l_{w} .
$$

The accurate measurement of the friction coefficient between meshing acetal polymer gears is essential, but this needs other accessories that are more expensive. This study focused on the new design and wear behaviours of acetal gears only.

\subsection{Experimental Procedures}

(a) Assemble the machine parts according to the type of gears to be tested.

(b) Make sure that their snap rings safely mount all of the bearings and gears.

(c) Run the machine for approximately 5 minutes without any external load to make sure that the gears to be tested are smooth and do not have any surface contaminant. 


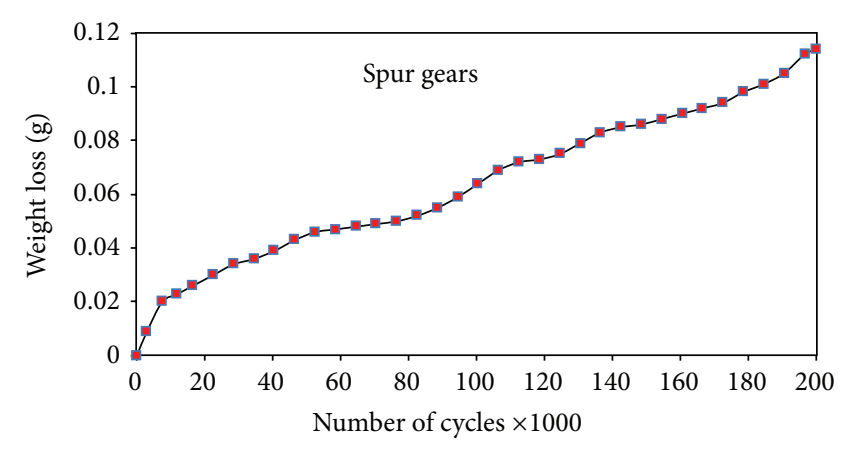

(a)



(c)

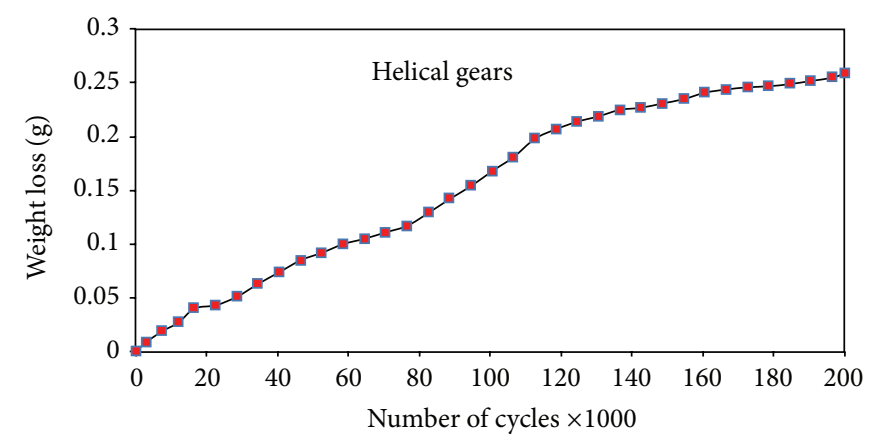

(b)

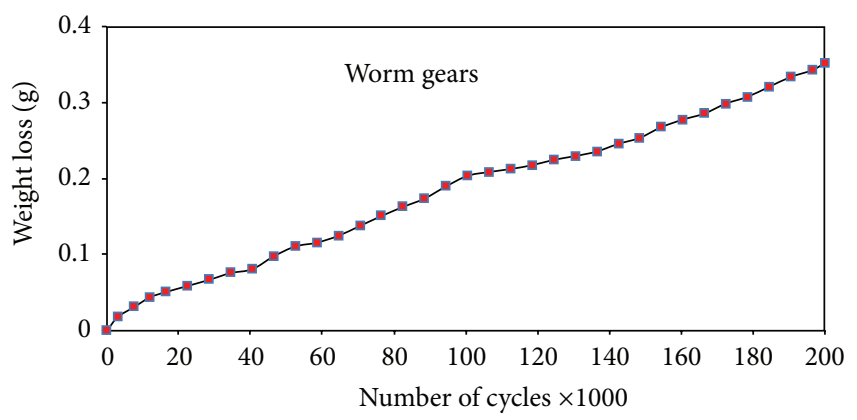

(d)

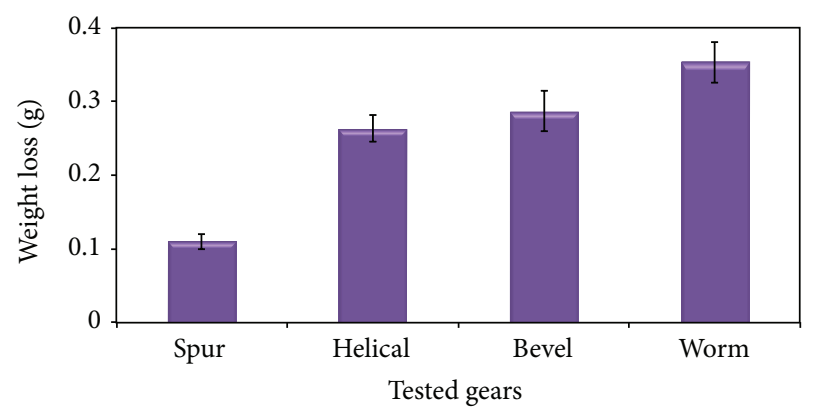

(e)

FIGURE 7: Wear of the (a) acetal spur gears, (b) acetal helical gears, (c) acetal bevel gears, (d) acetal worm gears, and (e) total weight loss for each gear with standard division errors after three-time repeat.

(d) Measure the mass of the driving gear. This measurement is considered the initial point.

(e) Add the spring and mass system. Adjust the mass and the lever hole where the spring can be hung to obtain the desired load. The load can be measured using the LCD (liquid crystal display or digital number display) in the controller. It is worth mentioning that torque transducer had capacities $20 \mathrm{Nm}$, which was used to adjust the applied torque.

(f) Run the machine for a certain interval of time and measure the new mass of the gear.

(g) Repeat step (f) several times until the total number of desired cycles is attained.

(h) Now, several points are obtained between the cycles and the weight loss. A curve between these two variables can be plotted to show the wear rate against the motor cycles.

\section{Results and Discussion}

The weight loss of each gear was measured at periods of time convergent every 6 minutes, not two measurements only at the beginning and at the end of the test, in order to plot the final relationship between weight loss and number of cycles with high accuracy. Furthermore, each gear sample was tested three times to measure the wear loss (by weight) using a high sensitivity electronic weighing balance with accuracy $\left(10^{-2}\right.$ gram $)$ and then calculate the average weight loss.

Two types of wear were found during the experiment: rolling type and sliding type. Maximum sliding was achieved 
TABLE 6: The wear phases for different types of polymer gears.

\begin{tabular}{|c|c|c|c|}
\hline & Running-in phase & Linear phase & Rapid-wear phase \\
\hline Acetal pair of spur gears & $\begin{array}{l}\text { Duration from } 0 \text { to } 15 \times 10^{3} \\
\text { cycles weight loss } 2.3 \mathrm{mg}\end{array}$ & $\begin{array}{c}\text { Duration from } 15 \times 10^{3} \text { to } \\
200 \times 10^{3} \text { cycles weight loss } 11 \mathrm{mg}\end{array}$ & Not found \\
\hline Acetal pair of helical gears & $\begin{array}{l}\text { Duration from } 0 \text { to } 16 \times 10^{3} \\
\text { cycles weight loss } 4 \mathrm{mg}\end{array}$ & $\begin{array}{c}\text { Duration from } 16 \times 10^{3} \text { to } \\
85 \times 10^{3} \text { cycles weight loss } 14 \mathrm{mg}\end{array}$ & $\begin{array}{l}\text { Duration from } 85 \times 10^{3} \text { to } \\
200 \times 10^{3} \text { cycles weight loss } \\
26 \mathrm{mg}\end{array}$ \\
\hline Acetal pair of bevel gears & $\begin{array}{l}\text { Duration from } 0 \text { to } 45 \times 10^{3} \\
\text { cycles weight loss } 7 \mathrm{mg}\end{array}$ & $\begin{array}{l}\text { Duration from } 53 \times 10^{3} \text { to } \\
145 \times 10^{3} \text { cycles weight loss } 16 \mathrm{mg}\end{array}$ & $\begin{array}{l}\text { Duration from } 53 \times 10^{3} \text { to } \\
200 \times 10^{3} \text { cycles weight loss } \\
29 \mathrm{mg}\end{array}$ \\
\hline Acetal pair of worm gears & $\begin{array}{c}\text { Duration from } 0 \text { to } 12 \times 10^{3} \\
\text { cycles weight loss } 4.4 \mathrm{mg}\end{array}$ & $\begin{array}{c}\text { Duration from } 12 \times 10^{3} \text { to } \\
90 \times 10^{3} \text { cycles weight loss } 19 \mathrm{mg}\end{array}$ & $\begin{array}{c}\text { Duration from } 90 \times 10^{3} \text { to } \\
200 \times 10^{3} \text { cycles weight loss } 35 \mathrm{mg}\end{array}$ \\
\hline
\end{tabular}

at the root of a tooth. Ideally, there is pure rolling when the contact is on an imaginary line between the wheel centres because of the identical velocity vectors for the two contacting surfaces. Three phases of wear (running-in phase, linear phase, and rapid-wear phase) were achieved in all types of test acetal polymer (spur, helical, bevel, and worm) gears.

Many reports have listed the test conditions of polymeric spur gear, but, for other types of gears (helical, bevel, and worm), unfortunately it is not valid, because polymeric materials have a low strength and other types of gears generate an additional axial load causing an overload leading to rapid failure. To avoid the rapid failure and stay in safe zone, the experimental conditions for all gear types were selected according to the lower values, particularly at a speed of $1420 \mathrm{rpm}$, a torque of $4 \mathrm{Nm}$, and test duration of $200 \times 10^{3}$ cycles $[10,13,14]$.

As shown in Figure 7, the maximum wear rates occurred at the final wear stage in all gear types, particularly in the helical, bevel, and worm gears because these types of gears generate an additional load, which is called the axial load. In addition, several different forms of stresses were involved. The bending of a tooth causes root stresses, whereas contact causes surface pressures to vary, particularly when the number of tooth pairs in a mesh changes (for the helical, bevel, and worm gears). Finally, Table 6 illustrates the different phases of wear.

\section{Conclusion}

The wear behaviours of various types of acetal polymer gears (spur, helical, bevel, and worm) were studied in this paper using a TS universal test rig, which was particularly built for this purpose. The loading mechanism in the test rig depended on the theory of the block brake mechanism. The performed experiments with a torque of $4 \mathrm{Nm}$ and a test duration of $200 \times$ $10^{3}$ cycles showed that the wear resistances of acetal polymer spur gears were mostly consistent with the previous results. The wear rate of the helical, bevel, and worm gears increased by $56 \%, 60 \%$, and $68 \%$, respectively, compared to that of the spur gears. The presence of axial loads in helical, bevel, and worm and their different geometries lead to different types of stress, such as bending stress and contact stress.

\section{Conflict of Interests}

The authors declare that there is no conflict of interests regarding the publication of this paper.

\section{References}

[1] K. Mao, The performance of dry running non-metallic gears [Ph.D. thesis], University of Birmingham, Birmingham, UK, 1993.

[2] K. Mao, "A new approach for polymer composite gear design," Wear, vol. 262, no. 3-4, pp. 432-441, 2007.

[3] K. Mao, W. Li, C. J. Hooke, and D. Walton, "Friction and wear behaviour of acetal and nylon gears," Wear, vol. 267, no. 1-4, pp. 639-645, 2009.

[4] T. J. Hoskins, K. D. Dearn, S. N. Kukureka, and D. Walton, "Acoustic noise from polymer gears-a tribological investigation," Materials \& Design, vol. 32, no. 6, pp. 3509-3515, 2011.

[5] K. D. Dearn, T. J. Hoskins, D. G. Petrov, S. C. Reynolds, and R. Banks, "Applications of dry film lubricants for polymer gears," Wear, vol. 298-299, no. 1, pp. 99-108, 2013.

[6] D. J. Hargreaves and A. Planitz, "Assessing the energy efficiency of gear oils via the FZG test machine," Tribology International, vol. 42, no. 6, pp. 918-925, 2009.

[7] H. Düzcükoğlu, "PA 66 spur gear durability improvement with tooth width modification," Materials and Design, vol. 30, no. 4, pp. 1060-1067, 2009.

[8] E. Letzelter, M. Guingand, J.-P. D. Vaujany, and P. Schlosser, "A new experimental approach for measuring thermal behaviour in the case of nylon 6/6 cylindrical gears," Polymer Testing, vol. 29, no. 8, pp. 1041-1051, 2010.

[9] S. Kirupasankar, C. Gurunathan, and R. Gnanamoorthy, "Transmission efficiency of polyamide nanocomposite spur gears," Materials and Design, vol. 39, pp. 338-343, 2012.

[10] S. Yousef, A. Khattab, M. Zaki, and T. A. Osman, "Wear characterization of carbon nanotubes reinforced polymer gears," IEEE Transactions on Nanotechnology, vol. 12, no. 4, pp. 616-620, 2013.

[11] S. Yousef, A. Khattab, T. A. Osman, and M. Zaki, "Effects of increasing electrodes on CNTs yield synthesized by using arc-discharge technique," Journal of Nanomaterials, vol. 2013, Article ID 392126, 9 pages, 2013.

[12] S. Yousef, A. Khattab, T. A. Osman, and M. Zaki, "Fully automatic system for producing carbon nanotubes (CNTs) by using arc-discharge technique multi electrodes," in Proceedings 
of the 1st International Conference on Innovative Engineering Systems (ICIES '12), pp. 86-90, IEEE, December 2012.

[13] H. Imrek, "Performance improvement method for Nylon 6 spur gears," Tribology International, vol. 42, no. 3, pp. 503-510, 2009.

[14] E. Letzelter, M. Guingand, J.-P. de Vaujany, and P. Schlosser, "A new experimental approach for measuring thermal behaviour in the case of nylon 6/6 cylindrical gears," Polymer Testing, vol. 29, no. 8, pp. 1041-1051, 2010. 

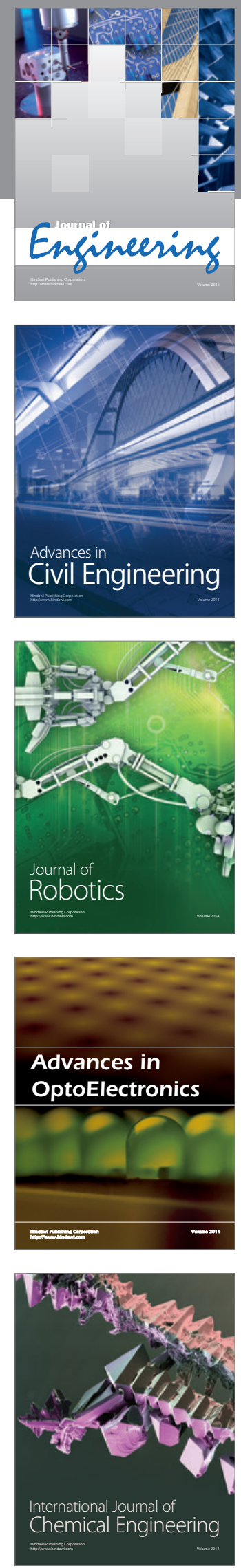

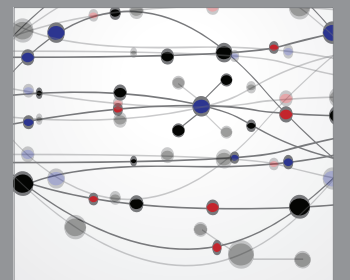

The Scientific World Journal
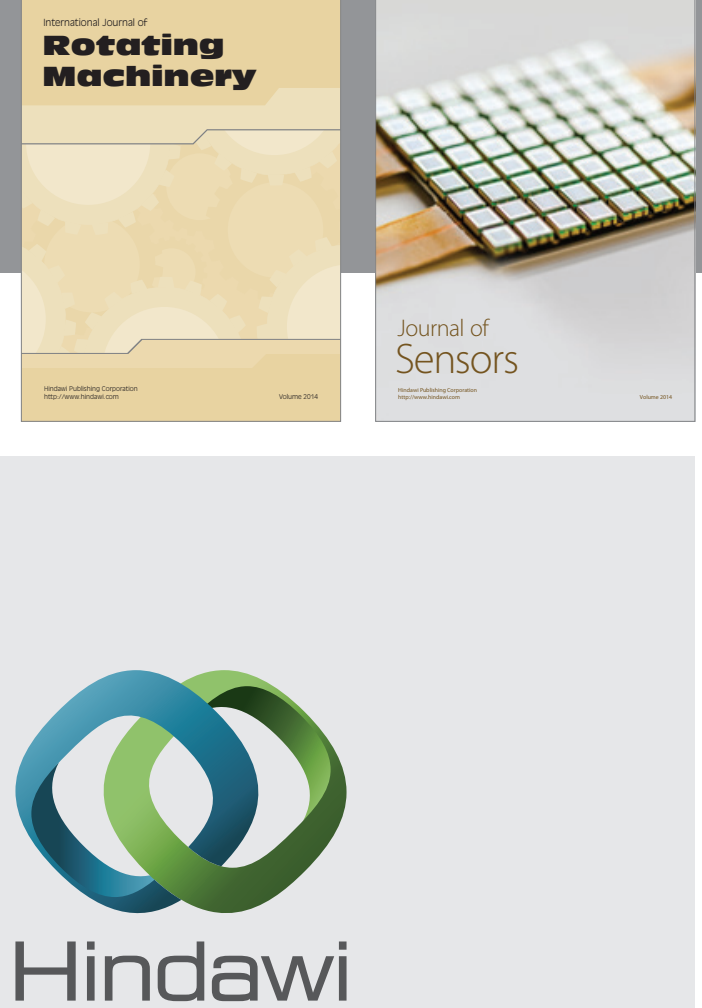

Submit your manuscripts at http://www.hindawi.com
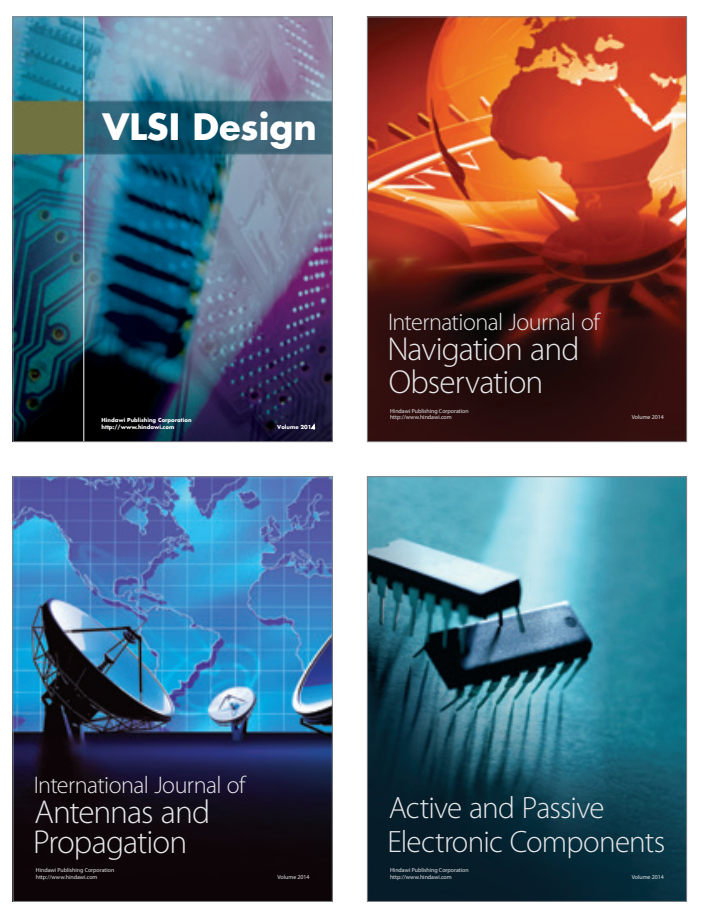
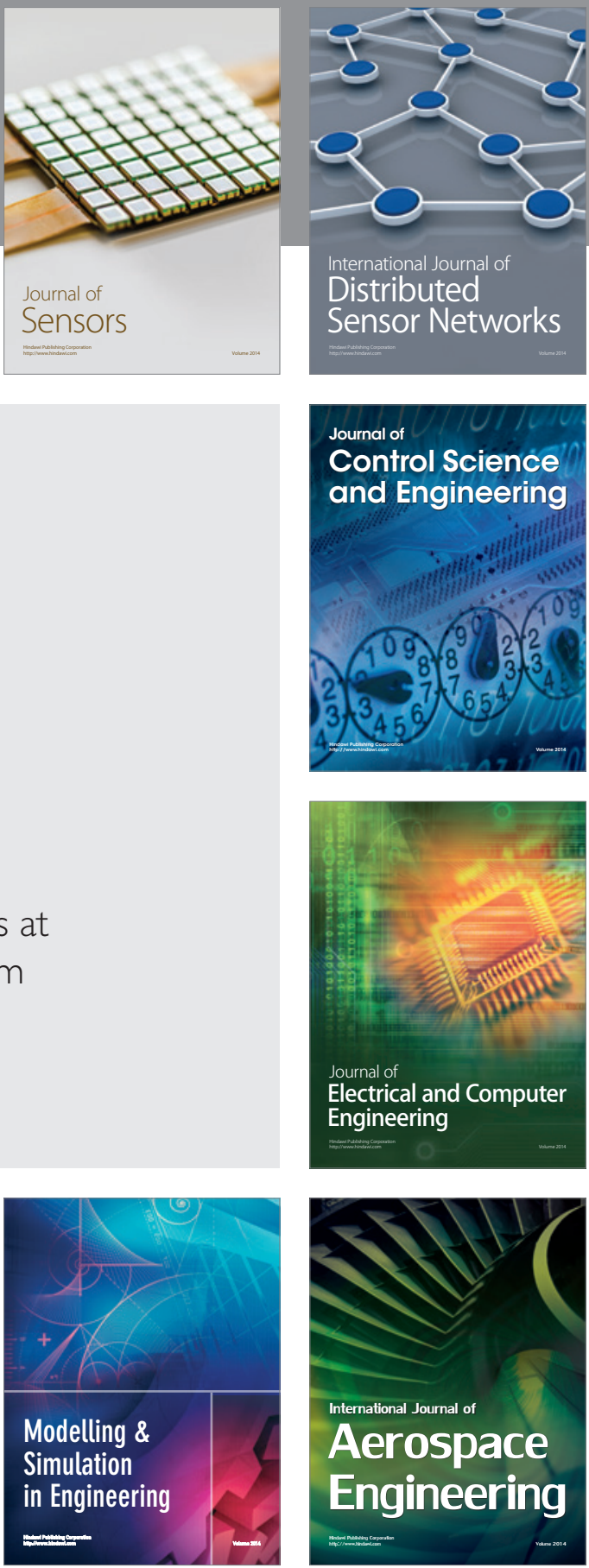

Journal of

Control Science

and Engineering
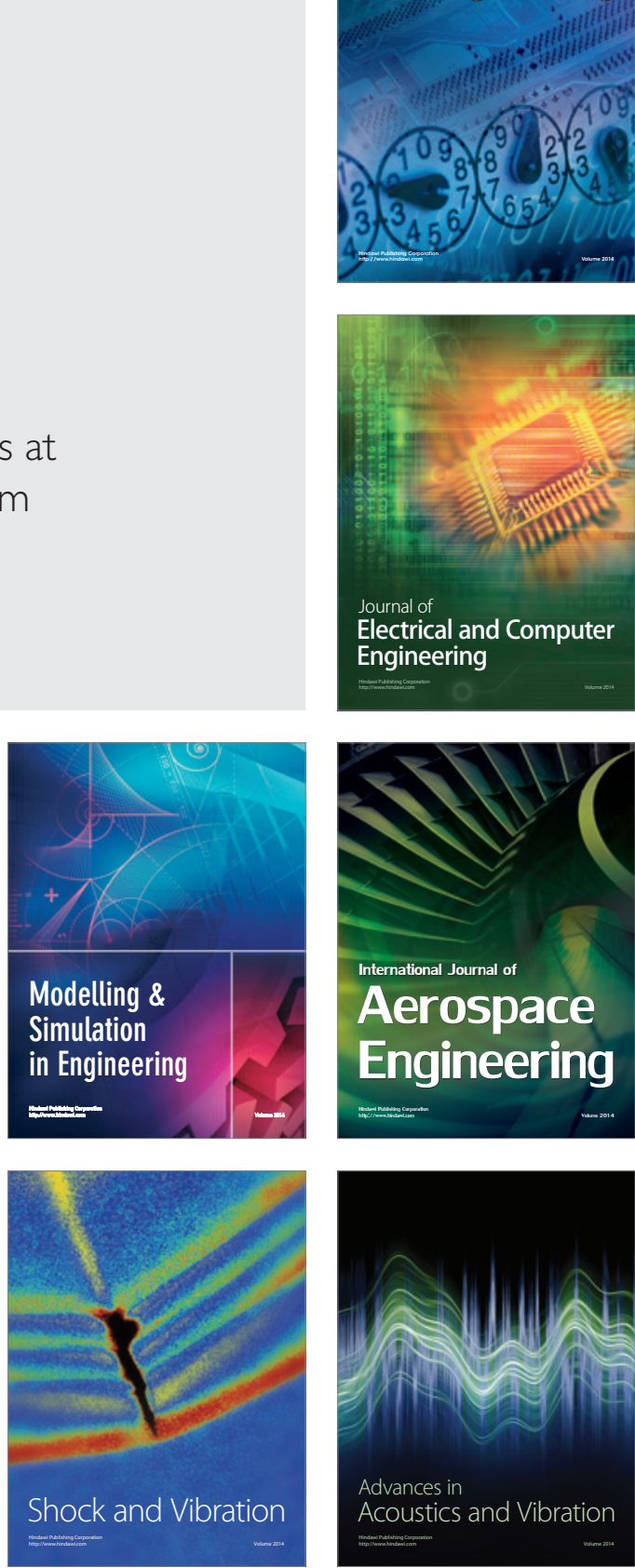